\title{
Language Teachers' Digital Mindsets: Links between Everyday Use and Professional Use of Technology
}

\section{Sofia Cementina}

Innovations in digital technologies have the potential to alter how people think, learn, communicate, and collaborate with others. Whereas changes in technology and its affordances have transformed social contexts and learning environments, instructors' beliefs about digital technologies and pedagogy can affect technology integration behaviours and language teaching practices. This study used a twophase approach to gain insights into teachers' digital mindsets and their personal and professional use of technology. In total, 50 teachers were surveyed regarding their technological beliefs and practices, and, among them, three second language teachers were selected and interviewed. Results illustrate that participants recognized and embraced the affordances of digital technologies in their own lives, yet they failed to see their significance in language teaching and learning. Their attitudes and intentions associated with technology uses were compartmentalized; while teachers' everyday practices were more digital and socially mediated, they struggled to adopt more technology-based teaching practices. Participants identified the lack of training in technology integration in language teaching hindered their use of digital resources, but findings indicate that the teachers' reluctance to explore emerging technologies and their own technological beliefs and experiences influenced their mindset and teaching practices. Implications and recommendations for second language instruction are discussed.

Les innovations de la technologie numérique ont le potentiel de modifier nos manières de penser, d'apprendre, de communiquer et de collaborer. Or, même si l'évolution technologique et ses affordances, ou potentialités, ont transformé les contextes sociaux et les milieux d'apprentissage, les croyances des professeurs concernant les technologies et la pédagogie numériques peuvent néanmoins influer sur les comportements relatifs à l'intégration des technologies aux pratiques liées à l'enseignement des langues. La présente étude est le compte rendu d'une approche en deux étapes adoptée afin de permettre de mieux comprendre la mentalité des professeurs face au numérique ainsi que leurs utilisations personnelles et professionnelles de la technologie. En tout, 50 professeurs ont fait l'objet d'un sondage concernant leurs croyances et leurs pratiques technologiques, y compris trois professeurs de langue seconde qui ont été sélectionnés pour une entrevue. Les résultats démontrent que même s'ils reconnaissent et recourent aux affordances des technologies numériques dans leur vie personnelle, les participantes et participants n'en reconnaissent point l'importance pour l'enseignement et l'appren- 
tissage des langues. Leurs attitudes et intentions en lien avec les utilisations de la technologie étaient compartimentées : même si leurs pratiques quotidiennes étaient plus numériques et paissaient davantage par les médias sociaux, les professeurs avaient du mal à adopter des pratiques pédagogiques davantage fondées sur la technologie. Les participantes et participants ont précisé que le manque de formations dans le domaine de l'intégration de la technologie dans l'enseignement des langues les empêchait d'utiliser les ressources numériques, mais les constatations de l'enquête indiquent toutefois que leur répugnance à explorer les nouvelles technologies ainsi que leurs croyances et expériences technologiques personnelles avaient une influence sur leur mentalité et leurs pratiques pédagogiques. L'étude renferme une discussion des implications de cet état de fait et offre des recommandations pour l'enseignement d'une langue seconde.

KEYWORDS: second language teaching and learning, digital mindsets, sociocultural learning, teacher beliefs, affordances of digital technologies

Technological innovations have the potential to greatly transform learning, communicative, and collaborative practices. Advancements in information and communication technologies (ICTs) have not only altered communication but also literacy (Coiro et al., 2008). Literacy competencies are no longer limited to reading and writing with ink and paper; "digital media [has] facilitated the creation of multimodal texts" (Hafner, 2014, p. 655), and the internet has contributed to the dissemination of "multiple streams of simultaneous information" (National Council of Teachers of English [NCTE], 2013). Literacy in the 21st century has been redefined as a multiple set of practices, and its competencies have been expanded to include digital and multimodal formats, and new social practices and ethical responsibilities (Coiro et al., 2008; Deyoe et al., 2014; Gee, 2012; Lankshear \& Knobel, 2006; Lewis, 2007; NCTE, 2013).

Studies indicate that students gain relevant skills beyond print-based literacies when they utilize digital technologies in the classroom (Tour, 2015). For instance, the adoption of familiar social networking or multiplayer gaming tools contributes to the development of affective attributes (i.e., motivation, self-confidence, and social skills) and cognitive processes (i.e., linguistic skills and problem-solving skills) of learners (Deyoe et al., 2014; Dörnyei, 2014; Kessler, 2018; Reinders \& Wattana, 2015). As teachers' knowledge and instructional practices impact student learning, it is vital that teachers' technological skills and practices be improved and enhanced to benefit learners (Deyoe et al., 2014; Haines, 2016; Parra et al., 2019).

The belief that adequate technological equipment in a school results in the inclusion of technology in teaching has prompted institutions globally to provide more hardware, software, and internet accessibility (Ertmer, 1999; Gonzalez \& St. Louis, 2013; Hew \& Brush, 2007; Hixon \& Buckenmeyer, 2009). 
This implies that access to equipment fundamentally transforms teaching practices and student learning (Deyoe et al., 2014). Still, the physical availability of computers and other technological tools is not enough; adequate training in their use and updating of teachers' technological proficiency are likewise essential (Deyoe et al., 2014; Ertmer, 1995; Haines, 2016; Hixon \& Buckenmeyer, 2009; Parra et al., 2019). Moreover, it has been suggested that other barriers to technology integration in lessons include "social and cultural factors" (Burnett, 2011, p. 434), beliefs about teaching and learning processes, and assumptions about technologies and their affordances (Ertmer, 2005; Haines, 2015, 2016; Hew \& Brush, 2007; Lankshear \& Knobel, 2006).

\section{Sociocultural Theory and Activity Theory}

Sociocultural theory (SCT) by Lev Vygotsky (1978) emphasizes that human cognition is largely influenced by its cultural, historical, and social environment (Lowe, 2011) and formed through participation in social activities (Johnson, 2009; Lantolf, 2007; Lantolf \& Pavlenko, 2001; Swain et al., 2015). It is, therefore, essential to examine the context alongside an individual's development if second language (L2) teaching and learning processes are to be studied (Swain et al., 2015). Moreover, SCT proponents believe that learning occurs over time (Swain et al., 2015). Thus, understanding a language teacher's technological knowledge and beliefs involves the examination of a teacher's familiarity and utilization of particular technologies for different pedagogical purposes, assuming that one's knowledge has evolved (Johnson, 2009) and applied to one's teaching practices (Harris et al., 2009).

Mediation is a fundamental SCT concept in this research. "Mediation occurs when something comes between us and the world and acts in a shaping, planning, or directing manner" (Swain et al., 2015, p. 2). Mediational means may be material (e.g., books, technologies) or symbolic artifacts (e.g., experiences, ideas, belief systems, language) that help humans develop higher cognitive functions (Lantolf, 2007; Swain et al., 2015). Individuals manipulate and modify these artifacts according to their physical and social contexts and culture (Johnson, 2009; Lantolf, 2007; Swain et al., 2015), and as these tools are passed on to others, they, in turn, are transformed by those tools (Lantolf, 2007; Lantolf \& Pavlenko, 2001; Swain et al., 2015). By being a member of a school community, teachers have access to cultural practices and tools of that particular social group. As they engage with others, they may "explicitly and implicitly [be] apprenticed" into uses of those artifacts according to the "norms, values, beliefs and hierarchies" of that community (Shin, 2014, p. 70). Individuals may "adopt, adapt, or resist" (Shin, 2014, p. 70) those norms and beliefs according to their own needs, motives, and experiences (Lantolf \& Pavlenko, 2001; Swain et al., 2015).

Another SCT concept is activity theory, which illustrates the complex and dynamic relationship between an individual and society and how that 
is mediated by artifacts and the community in which the individual belongs to and identifies with (Lantolf \& Pavlenko, 2001). Through this approach, it may be possible to investigate how human cognition and behaviour result from the interaction and participation of individuals within a society, their surroundings, and the mediating artifacts regardless of the contradictions between the elements (Antoniadou, 2011; Lantolf \& Pavlenko, 2001; Razfar et al., 2011; Swain et al., 2015). The activity theory allows the understanding of an individual's cognitive processes, including one's ideologies, beliefs, and attitudes, and how these are influenced by the social environment and are "constantly co-constructed and renegotiated" (Lantolf \& Pavlenko, 2001) as the person engages with their immediate community and the society at large (Ertmer, 2005; Lantolf \& Pavlenko, 2001). Teachers' beliefs are also shaped by one's unique history and goals and motives for a particular activity. Therefore, to understand the mindsets and practices of language teachers, it is essential that these beliefs and disposition toward technologies be examined in their natural environment (e.g., home or classroom), which encompasses the concrete and abstract mediational means (e.g., digital technologies, ideas, or belief systems) and the immediate community (Lantolf \& Pavlenko, 2001).

\section{New Literacies}

Literacy has traditionally been described as varied ways of reading, writing, and constructing meaning through printed texts, leading to better cognitive skills and unequal opportunities and outcomes for different individuals (Gee, 2012; Lankshear \& Knobel, 2006; Warschauer \& Ware, 2008). Literacy was considered separate from sociocultural contexts yet linked to power, identity, and ideologies of certain groups of people, providing them with more privileges (Gee, 2012). However, with social changes and new perspectives regarding cognition, literacy became more than just reading and writing. People began to relate thinking to the people, materials, technologies, and social settings (Gee, 2012), changing it from a singular notion to a "plural set

of social practices: literacies" (p. 63). Furthermore, due to recent technological advancement, literacies have expanded to include knowledge in technological tools and multimodal texts, interpersonal skills for face-to-face and virtual collaboration and relationship building, creation/sharing of resources, and awareness in ethical and legal literacy practices (NCTE, 2013).

The prevalence of Vygotsky's sociocultural theory suggests that a different approach to literacy is possible (Gee, 2012; Lankshear \& Knobel, 2011). From a sociolinguistic perspective, literacy is socially situated (Gee, 2012; Lankshear \& Knobel, 2006; Tour, 2015) and linked to a particular society's communicative practices evolving from its economic, cultural, and historical contexts (Gee, 2012; Lankshear \& Knobel, 2006; NCTE, 2013; Tour, 2015). New literacies are, therefore, identified with and mediated by emerging digital technologies (Coiro et al., 2008; Kessler, 2018; Lankshear \& Knobel, 2011; 
Tour, 2015) and as these continuously progress, the concept of literacy also transforms along with "new social practices, skills, strategies, and dispositions" (Coiro et al., 2008, p. 14) required for their effective use (Lewis, 2007). New literacies are fundamental to people's full participation in a community (Coiro et al., 2008) involving a more collaborative, participatory, and distributed nature compared with conventional literacies (Lankshear \& Knobel, 2006, 2011; Tour, 2015), and, as such, individuals' language, actions, beliefs, and attitudes must be appropriate to the social context, purpose, audience, and mode (Coiro et al., 2008; Gee, 2012; Lankshear \& Knobel, 2006, 2011; Tour, 2015). Literacy, then, cannot be described as a "singular construct that applies to all contexts" (Coiro et al., 2008, p. 14) but it is multiple, diverse, multimodal, and complex.

Although it is challenging to keep up with technological resources, and the opportunities for learning and use (Coiro et al., 2008; Haines, 2015; Kessler, 2018; Tour, 2015), research shows numerous benefits when using digital technologies in language teaching and learning. Digital games, online blogs, or discussion boards have provided L2 students with a platform to practice the target language and interact with others, reducing their anxiety levels (Haines, 2015; Kessler, 2018; Reinders \& Wattana, 2015; Shin, 2014). Multimodal projects encourage students' creativity and develop students' leadership and social skills (Angay-Crowder et al., 2013). These studies indicate the necessity for technology-mediated social interaction that is crucial for student learning (Deyoe et al., 2014; Kessler, 2018).

Thus, teachers must have "both technological and pedagogical knowledge" (Haines, 2015, p. 165) to appropriately employ technologies in the classroom and to recognize the opportunities and constraints that new tools bring. Having a technology-equipped classroom may not necessarily impact teaching and learning, but the crux is how those technological tools are utilized for learning (Coiro et al., 2008; Haines, 2015; Warschauer \& Ware, 2008). Conversely, Lewis (2007) discusses the schools' excessive focus on tools and teacher training but they neglect to look into the users' mindsets. She maintains that a requisite for teachers is learning about new mindsets, which must gradually and incrementally change along with the new technologies, new practices, and new forms of communication. Ertmer (2005) likewise points out the necessity of confronting teachers' pedagogical beliefs that are integral to their "decision regarding whether and how to use technology for instruction [emphases in original]" (p. 27). Thus, changes in teaching practices begin with the teachers and their beliefs about "teaching, learning, and technology" (Ertmer, 2005, p. 27).

\section{Mindsets}

A mindset is a perspective or a set of beliefs, values, or assumptions that influences an individual's perceptions, accomplishments, and experiences 
(Lankshear \& Knobel, 2006). It may be formed through social constructs, enculturation, direct or indirect experiences, or a series of events (Ertmer, 2005). A mindset held by one person or a group of people can be so wellestablished that it continues to be the frame of reference in spite of societal changes due to technological advancement (Lankshear \& Knobel, 2006). An individual with a fixed mindset will continually view literacy as unchanged although it has evolved to include different practices and expectations based on new technologies (Lankshear \& Knobel, 2006).

Lankshear and Knobel (2006) differentiate between two divergent mindsets that may exist in school settings. The first mindset assumes that the world is essentially unchanged although it has become more "technologized" (p. 34); in language/literacy teaching, this implies the use of the same teaching processes, although more efficiently with new technologies in place. The second mindset recognizes the immense transformation of the world due to new technologies; thus, literacy teaching practices must be altered to accommodate and include the technological, social, and communicative changes.

Although studies in literacy education reveal that many teachers use technology in the classroom, teaching practices still tend to be teacher-centred and curriculum-based where technology is utilized for low-level tasks such as word processing, presentations, practice drills, or internet research (Ertmer, 2005; Lankshear \& Knobel, 2006). Lankshear and Knobel (2006) describe this as the "old wine in new bottles syndrome" (p. 55) wherein teaching and learning practices are essentially unaltered except that printed materials have been replaced by digital texts. Many teachers are merely finding methods to integrate technology in lessons and adjust or adapt teaching practices without changing their pedagogical beliefs (Ertmer, 2005; Lankshear \& Knobel, 2006). These practices may reflect beliefs from the first mindset (Lankshear \& Knobel, 2006) where student-teacher roles are unchanged, literacies are seen as conventional, and technologies are mainly tools for producing outputs in the classroom (Ertmer, 2005; Lankshear \& Knobel, 2006). Conversely, the second mindset views technologies as tools that enable users to participate, collaborate, and establish relationships aside from being a source of widespread information (Lankshear \& Knobel, 2006). Individuals with this mindset recognize new literacies as the norm because technological changes have brought about varied and more socially situated ways of producing content, making meaning, and communicating with others requiring more sophisticated literacy skills (Lankshear \& Knobel, 2006, 2011; NCTE, 2013).

Individuals engage with technologies according to their own needs, beliefs, and unique ways as members of society. A closer examination of language teachers' mindsets allows us to explore what they "value in their experiences with digital technologies and what assumptions orient them towards new digital literacy practices" (Tour, 2015, p. 128). Looking into their personal and professional digital technological practices likely enables us to 
understand why technology integration in the language classroom continues to be a challenge.

\section{The Present Study}

The above literature suggests that teachers' beliefs are associated with digital technology integration in their everyday lives, which impacts their teaching practices. Thus, this research aimed to gain some insights into Philippine high school language teachers' assumptions about digital technology and these technologies' affordances for personal and professional use, and how these may affect their teaching pedagogy. This study was guided by the following two questions:

Research Question 1: What are high school language teachers' beliefs and perspectives about digital technologies?

Research Question 2: How do these same language teachers utilize digital technologies in their daily lives and integrate them into their classroom practices?

\section{Methodology}

\section{Data Collection}

Data for this research were collected over a period of 2 weeks in spring 2015 at an urban private school in the Philippines. A survey approach and specific case study principles were employed to gather both quantitative and qualitative data from the participants in two stages.

In Stage 1, data were initially collected through a paper-based survey questionnaire to elicit teachers' pedagogical beliefs regarding the impact of technology on teaching and student learning and their personal and professional uses of technology. The three-part questionnaire included items adapted from Park and Ertmer's (2007) Teachers' Beliefs Regarding Technology Use Survey (TBTUS) and the PRB Teacher Technology Inventory Survey. Using a Likert-type scale, educators self-reported their personal and pedagogical beliefs associated with the usefulness of technology. The open-ended questions asked for opinions on available technology, the motivating or impeding factors in technology integration, and desired technology training. Years of teaching experience, content areas taught, and access to digital technologies were elicited in the demographic section.

Survey responses and comments were categorized to search for patterns and recurring themes relevant to the research questions. Numeric results were analyzed alongside qualitative responses to identify relationships or contradictions in teachers' beliefs and teaching practices. Subgroups in the demographic section, such as age and length of teaching experience, were 
examined to see relationships between these and teachers' technological beliefs and practices. Answers to the open-ended questions were categorized to identify emerging patterns or trends, to help clarify the technological and teaching context and help infer generalizations about the group's technology assumptions and usage. Survey results will only be discussed to provide background and context for this study's findings. The research examined here focuses on three individual case studies, with participants selected from this Stage 1 survey research, for a more in-depth look at high school language teachers' perspectives and technology use.

Stage 2 of this research utilized case study principles involving participant-generated photographs and semistructured interviews. This was a replication of Tour's (2015) study applying a case study approach with photographs and "two one-hour open-ended interviews . . . with each participant" (p. 128). In her study, she examined five Australian language teachers' personal and professional use of technologies but discussed only three particular teachers' practices, which represented "a diversity of experiences with digital technologies" (Tour, 2015, p. 128). She conducted a thematic analysis of the photos and interviews, searched for patterns, and generated initial codes, which she constantly reviewed before identifying themes and creating a report.

In Stage 2 of this study, the three participants selected for these case studies shared more detailed information regarding their personal and professional technological practices through semistructured interviews. With their permission, these were audio-recorded, transcribed, and analyzed for thematic patterns. They elaborated on the photographs, which included audiovisual aids (e.g., projectors and televisions), mobile devices (e.g., laptops and smartphones), and communication platforms and software (e.g., Facebook and Microsoft Office). The photos were visually analyzed and classified to explore possible themes and to gain more insights about the selected teachers' views about digital technologies. Findings from the interviews and photographs were closely examined alongside the survey data to identify similarities or differences between the selected teachers' beliefs and practices with the rest of the faculty.

\section{Participants}

Stage 1 participants $(n=50)$ included preschool, elementary, middle, and high school teachers, representing all subject areas; the language instructors taught English, Filipino, and Chinese. All, except 13, were female. Most respondents (87\%) reported being in the 20 to 40 age group, while six $(12.7 \%)$ were aged 41 and above. A total of 22 teachers (46.8\%) had 1 to 3 years of teaching experience while seven (14.9\%) taught for 4 to 7 years. Four (8.5\%) participants had 8 to 10 years of experience, and $14(29.8 \%)$ had been teaching for 11 or more years. Convenient sampling was used as this researcher 
was on-site to conduct a one-off workshop on technology integration within different content areas as part of the faculty's annual in-service professional development session.

From this Stage 1 sample, three language teachers were selected for the second phase of the study based on the following factors: (a) language courses taught, which included English, Filipino, and Chinese; and (b) years of teaching experience, ranging from 1 to 5 years, 6 to 10 years, or 11 or more years. Having three teachers allowed the close examination of how the content area, language component, and teaching experience affected specific teachers and their assumptions and attitudes toward technology integration. Comparative and contrasting elements between their own and others' beliefs and practices were noted.

The table below (Table 1) presents a summary of the three participants:

Table 1

Background Information about the Three Participants

\begin{tabular}{lllcc}
\hline Participant* & Age Range & Subject & $\begin{array}{c}\text { Year Level Being } \\
\text { Taught }\end{array}$ & $\begin{array}{c}\text { Years of Teaching } \\
\text { Experience }\end{array}$ \\
\hline Andrew & $20-30$ & English & 11 & 1 \\
Nathan & $20-30$ & Mandarin Chinese & $9-11$ & 4 \\
Lily & $31-40$ & Filipino & 11 & 8 \\
\hline
\end{tabular}

${ }^{*}$ Pseudonyms have been used for confidentiality and anonymity of the participants.

Andrew, a novice English as a Second Language (ESL) teacher, hailed from a small town without internet access; his correspondence with his family primarily involved mobile phone usage. When he moved to the city for higher studies, he learned about software applications. He described himself as an active user of social networking sites, a technical enthusiast of electronic gadgets, and a digital gamer.

Nathan had been teaching Chinese as a second language for a year in this school and 3 years in an international school in Manila. He received his teaching degree from a Chinese university on a scholarship. He maintained that technology plays a huge role in his life, especially in communicating with his family and friends, and in learning.

Lily was the most experienced teacher for she had been teaching Filipino for 8 years. Her technological uses involved downloading of resources from the internet and constant communication with her family and nonfamily members on Facebook. Her overall attitude toward technology indicated ease of use for work, communication, and building relationships. 


\section{Findings and Discussion}

Affordances of digital technologies that the three participants primarily identified were on connectivity and communication. With these affordances, participants demonstrated their awareness of how technologies have changed the world and their routines (Lankshear \& Knobel, 2006) and acknowledged the centrality of technologies in their own lives. The three language instructors described their exploration and attempts to include multimodal tasks in both personal and professional domains, but these were restricted based on their knowledge, confidence, and competence in technology use. They differed in their perceptions, utilization, and experiences with digital technologies in various contexts, which had particular implications in their teaching practices.

New literacies. With Web 2.0 technologies, the concept of literacy has included technological skills, a collaborative and participatory culture, and the production and sharing of multimodal texts online (Coiro et al., 2008; NCTE, 2013). The three language teachers indicated their efficiency and versatility in their personal technological practices involving mobile phone use, internet searches, and digital communication through social networking sites and email. These practices suggest that connectivity, strong social ties, and a sense of belonging to a community were fundamental to their digital mindset (Lankshear \& Knobel, 2011).

Andrew portrayed his communicative preferences for digital texts, "broadly defined as emails, SMS text messages, and more multimodal texts, such as websites and computer games" (Burnett, 2011, p. 437) in contacting his family, friends, and colleagues.

When I try to reach out to my [relatives] in faraway places, instead of having to write them a letter by hand and have it delivered by post, I can just contact them directly through Messenger. I can simply [find] them on Facebook and learn where they are or what they're doing based on their posts.

Andrew's constant use of social media indicated his belief that technology acts as a quick and convenient "tool to connect with others" because of its real-time connection with relatives or friends and to keep updated on their activities. Similarly, Lily established an online identity on Facebook and participated actively on the site (Merchant, 2009) by frequently interacting with people she knew, by uploading images, and by commenting on posts (Lankshear \& Knobel, 2011). She viewed Facebook as a site whose "express purpose [is to] foster social ties" (Lankshear \& Knobel, 2011, p. 177) with family, friends, and school community members. Both Andrew and Lily emphasized the convenience of social media and their pleasure at participating in an online society (Burnett, 2009), suggesting new literacy practices (Lankshear \& 
Knobel, 2011; Tour, 2015) driven by the belief that connectedness and communication are essential in sustaining relationships (Burnett, 2011).

Yet, this notion was not evident in Andrew's communicative practices with his students. For him, an online relationship with students was inappropriate unless they were "really trustworthy," and stressed that "those sites are only for personal use." In this regard, his assumptions about social networking and teaching practices were conflicted. He claimed that online communication is vital in maintaining relationships in this technological age and that it was his duty as a language instructor to teach communication skills through different means:

The word social means [students] also have to be gregarious with other people, not just with those who are here but who are also in other places as long as they try to see or check how these people are in their accounts. As an English teacher who promotes or should promote effective communication, then it really is my responsibility.

Yet, interestingly, he did not consider email writing as a communicative task. His lesson on emails was impeded by a student's refusal to open an email account and by the limited number of students with personal email addresses. He may have associated emailing with Web 2.0 technologies that are "only for personal use," and a communicative task that should be taught at home rather than in school because he apparently regarded literacy in the outside world and in school differently.

Unlike Andrew, Lily willingly connected with her students through emails and social media:

My students add me as their friend, so I always monitor what they post on Facebook because we [teachers] always remind them about how to use social media. They have to think if it is true, if it is kind, or appreciative or if it is necessary to say [something]. They are aware that in this school some things are not supposed to be said or done on social media.

By connecting with students on Facebook, she believed that she could monitor their online identities. Her openness in allowing students to see her active participation on Facebook indicated her awareness that a social networking site is a "digitally-mediated and participatory literacy practice" (Merchant, 2009, p. 113) and a medium for communicating with the students. As an educator, she understood that learning may occur in those digital spaces and that relationships with students today do not only occur in class, but also in social networking sites. She viewed digital technology as a progressive and convenient aspect of society that had transformed both her life and her teacher role.

Still, Lily did not appear to recognize other affordances of social networking sites for language teaching. Teaching about online registers or etiquette 
did not cross her mind because of students' preference to communicate in English in school and on social media. Because she teaches Filipino, she presumed that this was a task for English instructors. She had not considered the notion that online technological tools may be adjusted and utilized as a platform for teaching Filipino as a language based on her pedagogical objectives (Haines, 2015).

Compared with Andrew and Lily, Nathan used more varied digital technology applications in his personal and professional life. He used different applications (e.g., Facebook, Gmail, WeChat, and QQ) for his family, and Filipino and Chinese friends, to conform with the frequently used social networking sites in both countries. His mindset toward digital technology focused on communication and connectedness:

Since we're in the 21st century, we really need technology. It's my way of socializing. It's not like before. If I wanted to talk to my friend, I would have to go to his place. Now, we can just call and text each other and that's good enough. For me, it's important because I see it as very convenient. And in my family, we use Facebook. My family has a group there. We rarely use texts or calls anymore. We use online stuff to communicate with each other.

Nathan's only stipulation is that he must maintain separate accounts for his personal and professional uses. He encouraged students to open personal email accounts, and distributed lesson materials digitally. Aside from teaching the Chinese culture and language, he stressed the necessity and benefits of having an email account so students can learn email etiquette and email writing conventions early.

Another medium that Nathan and Andrew used to interact with others was online multiplayer games. Andrew claimed the games strengthened his relationships with others and enabled him to establish rapport with his students by frequently discussing Defense of the Ancients (DotA) gaming strategies with them. He asserted that games can promote language learning by encouraging students to describe, compare, and discuss the abilities of their troops in $\operatorname{Dot} A$ in the target language. Although he did not use the actual game as an explicit language learning tool, he recognized that it may be an opportunity for students to utilize the target language in sharing their gaming knowledge in class to boost their self-confidence and self-esteem.

Andrew's preferences in exchanging ideas about video games with students were consigned to the classroom. As a fairly new gamer, he may have perceived multiplayer games as a leisure activity irrelevant to language learning. As a new language instructor, he has not recognized the games' potential for vocabulary learning, development of reading and listening skills, opportunity for pragmatic competence (Reinders \& Wattana, 2015), or fluency practice (Derwing et al., 2008). With his limited experience in "playful interactions with technology" (Burnett, 2011), it may take Andrew some 
time before he can recognize the affordances of digital gaming in L2 learning (Graham, 2008). In fact, Ertmer (2005) claims that it typically takes teachers 5 to 6 years to accumulate technology competence before they can alter their teaching practices. As Andrew is a novice teacher, this could be a reason for his disassociation of digital gaming with educational purposes.

Meanwhile, Nathan strongly believed that digital technologies can enhance L2 learning, offer alternative means of learning, and be utilized as tools for communication and literacy: "It is not only in the classroom where students are learning it [target language]." Nathan employed an online multiplayer game, League of Legends $(L O L)$, to tutor and interact with students in Chinese. Digital games can encourage L2 learners to use the target language because these are engaging, motivating, and enjoyable (Reinders \& Wattana, 2015). Furthermore, the acquisition of higher levels of fluency (Derwing et al., 2007), an increase in self-confidence in the use of the language, and the opportunity for authentic L2 use (Reinders \& Wattana, 2015) are possible through online games. These may be used as an alternative approach to literacy and learning as they reflect the participative, communicative, and collaborative nature of new literacies (Lankshear \& Knobel, 2006).

In contrast, Lily showed little inclination in viewing online multiplayer games' potential for socialization, communication, or L2 learning (Chik, 2011) because they ostensibly did not conform to her lifestyle and accustomed teaching practices. Like Andrew, she had no perception of games' educational value as a new resource for language skills development. In the gaming world, Lily can be described as an "outsider" (Lankshear \& Knobel, 2006). Her lack of experience or history with games is a barrier to her understanding of how they may be used for language learning (Chik, 2011; Lankshear \& Knobel, 2006). Barlow believes that this insider-outsider concept is due to age (as cited in Lankshear \& Knobel, 2006, p. 35) because people over the age of 35 are generally outsiders to new technologies.

Technology Integration in Teaching. The three language instructors primarily used technology for a more effective and efficient work performance. The ease in producing materials, researching information, and creating classroom presentations were among the technological affordances mentioned.

Andrew and Lily shared how presentations using technology-enhanced visual effects engaged and motivated students, and accommodated the needs of visual learners (Burnett, 2011). Lily emphasized that students "love [her] because [she's] not using the old style of teaching." Their technology use was an addition to existing teaching routines rather than a discovery or an assessment of its potential and limits for teaching pedagogy (Ertmer, 1999; Haines, 2015; Tour, 2015). Norton and Wiburg (1998) specify that teachers who utilize technology to improve familiar teaching practices may view a technologyintegrated classroom differently (as cited in Ertmer, 1999) compared with teachers who use technology with the students' future in mind and attempt to explore new methods of doing things (Lankshear \& Knobel, 2006). Although 
the availability of classroom technology was inadequate, how these accessible digital technologies were utilized for learning is essential (Coiro et al., 2008; Haines, 2015; Warschauer \& Ware, 2008). Andrew's and Lily's cognizance of their roles as language instructors was unaltered by technologies (Ertmer, 2005; Lankshear \& Knobel, 2006).

Andrew considered the use of technology was "more crucial" in developing students' receptive skills but unnecessary for developing their productive skills. "For speaking, you can do them orally. You can just put an imaginary podium and [students] can already share items or [answer] a fishbowl of questions. Writing can be done on paper anyway." These teaching methods, particularly the pen-and-paper method for writing and presentations, reflected the first mindset and the "old wine in new bottles syndrome" (Lankshear \& Knobel, 2006, p. 55), replacing paper and the blackboard with PowerPoint presentations. This still indicated a more teacher-centred and traditional literacy classroom (Ertmer, 1999, 2005) rather than a more collaborative, interactive, and participatory environment required in a technologically enriched, new literacies classroom (NCTE, 2013). He may have viewed the classroom as an "enclosed and purpose-specific" space (Lankshear \& Knobel, 2006, p. 38) where the development of speaking and writing skills should be contained. He was still dictated by "conventional literacies" (Lankshear \& Knobel, 2006, p. 30), suggesting that his understanding about the use of technology in language teaching has not yet been clearly conceptualized.

Meanwhile, Lily did not show any enthusiasm in learning about other technological tools for teaching. In fact, she articulated that her interest in technology was merely for offline applications. She claimed that the slow internet connection in school hindered the use of any other web-based app. Ertmer (1999) described how the lack of physical resources such as hardware and internet access can impede meaningful uses of technology in the classroom. She explained that schools needed to overcome these physical constraints for teachers to recognize the affordances of technology in education.

It, likewise, appeared that Lily lacked the motivation to incorporate more technology into her teaching (Gonzalez \& St. Louis, 2013). Barlow justified this through age, but Correa (2008) explained that it could be due to the shift in "control" (as cited in Gonzalez \& St. Louis, 2013, p. 231) in the classroom, implying her disinterest in relinquishing control. Presentations allowed her to maintain the "chalk and talk" method that she was familiar with (Ertmer, 1999, p. 51) while being "loved" by the students for using technology. Given that she was a seasoned teacher, altering her existing beliefs about her role in the classroom because of technology may have been too onerous. Lankshear and Knobel (2006), likewise, noted that teachers are the ultimate authoritative and expert figure in the classroom and are, therefore, unprepared for the challenges of a "distributed and collective authority and expertise" that new technologies bring (p. 38). 
Given the extensive literature on internet-based communications and L2 learning, Andrew and Lily need to develop an appreciation for technologymediated social interactions for their students (Haines, 2015; Shin, 2014). This may encourage learners to perceive language learning and use according to "social goals in particular social contexts" (Hafner, 2014, p. 657) as one's purpose, audience, and mode of communication can influence the way language is produced (Hafner, 2014; Shin, 2014), which, in turn, can lead to the formation of social identities (Norton \& Toohey, 2011; Toohey \& Dagenais, 2015).

In contrast, Nathan exhibited a different mindset regarding digital technologies and language learning, influenced by his own learning experiences and social and cultural contexts. As an L2 learner of Chinese himself, he relied on memorization, resulting in less familiarity in using the language.

My goal is for [students] is to communicate because they're learning a language. It should not only be memorization or writing. Because that's what happened to me when I was in high school. I don't want the same thing happening to them. They should be able to communicate in the language.

In addition, Nathan shared that he had training in integrating digital technologies in teaching Chinese during his preservice education. Because of this, his determination to create a well-developed and technology-enhanced Chinese curriculum demonstrated his desire for students to gain the ability to communicate well in the target language, have a functional L2 learning experience, and concurrently learn new literacies.

Nathan explored digital technology-mediated methods in teaching a second language. His students created video role-plays, and he used computerand web-based applications to create materials and collaborative games for his lessons. He used apps such as Hello Chinese for pronunciation drills, and Skype for assessing his students' Chinese conversational skills:

I asked [a Chinese friend] to talk to them using the content that we've learned in class. I would tell them to ask Lăoshī (Teacher) about something. Whatever his answer [was] and [they] understood it, [then they] can [translate] his answer to me.

In demonstrating how to write Chinese characters, he underscored the importance of certain apps because they were helpful in improving his students' writing skills. Engaging students through these different applications and multimodal digital texts indicate that Nathan valued the creativity, participation, experimentation, collaboration, and multimodality that reflect the second mindset (Lankshear \& Knobel, 2006). Development of students' language skills through digital technologies was also central to his approach (Tour, 2015), illustrating that he had perceived the affordances of these different technological applications for learning (Haines, 2013). 
Sociocultural influence. Andrew's and Lily's mindset and teaching practices embodied the school's typical culture and technological assumptions. Technology-integrated lessons meant content presentations or word processing activities for more effective information sharing, disregarding the social nature of digital technology. They and the other faculty members adopted this particular orientation; teachers' technical expertise emphasized information rather than interaction and communication, reflecting the first mindset where technology is used to improve current teaching and learning practices (Ertmer, 1999; Lankshear \& Knobel, 2006). They were satisfied with their teaching practices, which incorporated technology, but generally adopted low-level technological uses (Ertmer, 2005). They replaced conventional print-based literacies with something more "technologized" (Lankshear \& Knobel, 2006; Tour, 2015). Although those technology-based activities may have motivated and captured the interest of the learners, opportunities for further digital literacy for the students were not encouraged. Furthermore, such practices seemingly reflected traditional teaching and learning beliefs, the traditional teacher-student roles (Ertmer, 2005), and typified teaching practices in the local context (Burnett, 2011), which could be an outcome of their teacher preparation program (Burnett, 2009, 2011), their classroom experiences as learners (Lantolf \& Pavlenko, 2001), and the cultural teaching environment of the school (Antoniadou, 2011; Burnett, 2011; Ertmer, 2005; Lantolf, 2007; Swain et al., 2015).

Nathan, however, demonstrated that his teaching practice and use of technology in the classroom have been influenced by his contexts (Johnson, 2009; Lantolf \& Pavlenko, 2001; Swain et al., 2015). Because he was compelled to maximize the use of digital software and applications during his preservice education and at his previous workplace, he learned to integrate these in his teaching. At his current workplace, however, expectations for technologybased lessons became less critical due to fewer available resources. In fact, he demonstrated a reduction in technology usage in his teaching practices because he was the sole instructor doing so. He adjusted to the school culture and adapted to the school's technology-based teaching practices because he avoided being a "show-off" (Antoniadou, 2011; Ertmer, 2005; Lantolf, 2007; Swain et al., 2015). Yet, his ideologies regarding digital technologies remained the same, and he regularly shared his knowledge with others, experimenting with alternative modes of teaching, highlighting the support that technologies may bring to language development, and suggesting changes to teaching styles involving technology. He mentored colleagues in integrating technology in lessons, which may possibly influence their assumptions and perceptions of digital technologies, and, in turn, transform their teaching practices 
(Antoniadou, 2011; Lantolf \& Pavlenko, 2001; Razfar et al., 2011; Swain et al., 2015). He explained,

Technology is a tool in teaching [a] language. Its role is to encourage and motivate students because education at present is different from how it was before wherein it was only used in the classroom. I think that there is a need to integrate technology in the lessons because kids nowadays are different. And since the content is a second language, it's difficult for the teacher to teach it. It's not easy for the students to grasp the content. You really need to find a way how to teach it for the students to remember it long term or even use the language.

These three teachers' notions of new literacies and technological and pedagogical practices appear to be influenced by their mindsets and their contexts.

Mindsets. To reiterate, mindsets refer to a person's beliefs or values, which may affect how one approaches emerging technologies (Lankshear \& Knobel, 2006). The first mindset observed in educational settings views the world as unchanged although more "technologized" (Lankshear \& Knobel, 2006), and L2 instructors with this mindset utilize the same teaching pedagogy with more technologies for efficiency (Ertmer, 1999; Lankshear \& Knobel, 2006). Despite the prevalent use of digital technologies in societies, Lankshear and Knobel (2006) highlight that many schools and teachers are still "dominated by conventional literacies" (p. 30); consequently, individuals perceive social networking sites or online multiplayer games as a platform for communication with friends and family only or for learners' outside lives but not for educational settings. Andrew and Lily demonstrated this specific mindset. Their engagement in new literacies was largely done outside of school, and their perception of literacy in the real world and in school was dissimilar. They had yet to see the potentiality of social media or games as alternative methods for language development, socialization, participation, and communication (Chik, 2011; Kessler, 2018).

It is, likewise, probable that Andrew's and Lily's mindsets about teaching and technology impeded them from considering such sites as platforms for learning given that they had very limited experience in technology-integrated pedagogy during their preservice education (Ertmer, 1999; Parra et al., 2019). Their training in educational technology mostly comprised Microsoft Office applications workshops, suggesting that they had not had many opportunities to learn, observe, and consider classroom practices involving varied pedagogical methods using newer technology trends. The lack of computer literacy, insufficient practice in digital technologies, and fear of using new tools (Gonzalez \& St. Louis, 2013) may also be other factors contributing to their low-level technology use in the classroom. 
In fact, Andrew's and Lily's mindset on connectivity using web-based applications typified the assumptions of many faculty members. In total, 41 teachers (or $87 \%$ of the teachers surveyed) reported that social networking sites are for personal use rather than professional use. Perhaps due to lack of knowledge or experience in interactions with the wider school community (students, parents, experts) on these sites, nearly half of the faculty $(43 \%)$ were uncertain or wary about communicating with the school community on social media despite that $38(81 \%)$ teachers and $44(94 \%)$ of them believed that digital technologies can promote student collaboration and assist learners in sharing information, respectively.

Nathan's mindset differed considerably from the other educators due to his own L2 learning experiences, technology-based communication practices, preservice education, enculturation in China, and teaching context prior to his current school. His use of collaborative and participative sites in both domains is indicative of the second mindset demonstrating his optimum use of digital technologies to build and strengthen relationships with his family, friends, colleagues, and students (Lankshear \& Knobel, 2006). Unlike Andrew, Lily, and the other teachers, his beliefs regarding interactions, communication, and new literacies did not change based on the audiences. In addition, his training on digital applications during his preservice education and prior workplace indicated the impact an individual's past experiences with technologies can have on their mindset and pedagogy. His constant exploration of digital tools and attempts in technology teaching, despite the limitations present in the school, embody the second mindset that Lankshear and Knobel (2006) have described.

Moreover, by exploring a playful social practice (Graham, 2008), such as an online multiplayer game, to socialize, communicate, and teach a language (Chinese), Nathan recognized that online games may be a space to engage "insiders" or those who have grown up inside this digital world (Lankshear \& Knobel, 2006) to learn an L2. Because the world has changed through the emergence of new technologies and new social practices, he clearly understood that teaching practices must change as well.

\section{Summary and Recommendations}

The study's findings support literature suggesting that physical and human constraints can impede the integration of technologies in teaching (Ertmer, 1999; Gonzalez \& St. Louis, 2013). Although nearly half of the teachers $(44 \%)$ surveyed indicated their contentment with the technology in place, others claimed that lack of equipment and slow internet access (physical barriers) prevented them from integrating digital technologies in practice. An upgrading of educational technology facilities is needed as physical constraints inhibit teachers from even considering the use of more web-based applications. Schools can partner with software and technology corporations to 
provide more adequate technological facilities that meet the needs of the educators and the learners. In addition, human constraints such as the lack of training, experience, and confidence in the use of software, applications, and devices added to the limited exploration of digital technologies in the classroom. Given their unfamiliarity with many web-based education apps, teachers were unable to examine how teaching practices may change and student engagement be improved with more technologies.

Most teachers wished for more training in the use of desktop technologies, supporting the view that technology was an add-on in instruction rather than an integral component. They might have adapted pedagogical practices to include some technological applications, yet teaching styles were still associated with teacher-centred instruction (Ertmer, 1999, 2005; Lankshear \& Knobel, 2006). These technological practices, such as presentations, have been "given credence within educational contexts" (Burnett, 2009, p. 81) and are associated with "order and control" (Burnett, 2009, p. 80), positioning the teacher as an authoritative and knowledgeable figure in the classroom (Lankshear \& Knobel, 2006). In other words, the collaborative and participative nature of new literacies appeared to be far removed from their beliefs about what constituted "good teaching" in the school's context (Ertmer, 2005, p. 35). Their assumptions about Web 2.0 technologies, then, seem inconsistent with their pedagogical beliefs and teaching practices or irrelevant to the language courses they were teaching, further impeding the integration of digital literacies in the classroom.

\section{Pedagogical Needs}

Contextual factors appear to greatly influence language teachers' beliefs as well as their digital technology practices in teaching. While it was evident that new technologies significantly changed their own lives, there is still a disconnect between teachers' personal and professional lives as well as their technological practices in both domains. Perhaps schools can examine how digital practices are intersected into people's daily lives and explore how digital literacies may be integrated into teachers' classroom practices; unless teachers' pedagogical beliefs are changed, technological practices in teaching may remain the same.

Social and cultural factors that affect their technological practices appear to influence teachers' assumptions about teaching. Altering these beliefs may be challenging, considering that their pedagogical beliefs seem to be deeply rooted in their own learning experiences and social practices. Thus, teachers need to critically reflect on their assumptions regarding teaching and the appropriateness of digital literacies in their personal lives to transform their teaching practices. By acknowledging the need to evaluate their use of technology, teachers can be equipped to face the challenge of the constantly changing contexts, social practices, and technologies for them to identify the 
affordances of digital tools not only in their own lives but also in teaching (Haines, 2016; Kessler, 2018; Lawrence, 2018).

Research has likewise demonstrated the usefulness for L2 instructors to network with others who can share technology-mediated language learning practices and provide ongoing teacher training and support in technology integration. Novice and proficient language teachers can proactively connect with "peer mentors" (Lawrence et al., 2014, p. 17) who can share their technological and pedagogical approaches in integrating digital tools in language teaching contexts (Parra et al., 2019). Peer mentors can serve as role models in demonstrating the usefulness and applicability of technological applications in language learning and in encouraging familiarity with the tools (Haines, 2016; Nelson et al., 2019). With the assistance of mentors, teachers' mindsets on technology may be transformed.

An important aspect in teacher training is the ongoing support for learning new tools. Time and energy are components in experimenting with new tools to examine how they may be used to support language teaching pedagogy (Haines, 2015, 2016). Because teachers are often provided with limited or one-off technology training sessions during their preservice education or in-service training, teacher education institutions, local school boards, and organizations can collaborate in scheduling regular workshops for educators to address the rapid advancement of technological tools in education (Lawrence et al., 2014) and to appreciate the affordances of the tools in the classroom. As it can be more challenging for those teachers who are "digital immigrants" (Lankshear \& Knobel, 2006; Prensky, 2001) to learn new tools and adapt them for their teaching pedagogies, undertaking more handson technology integration sessions can assist teachers in the acquisition of the necessary knowledge and support in technology use in the classroom. In these sessions, teachers can be introduced to emerging technologies for language learning, including social media (Kessler, 2018), digital games (Reinders \& Wattana, 2015), automated devices for immediate spoken and written feedback, and augmented and virtual reality, which can encourage learners to interact with one another and immerse themselves in the "target language culture environment" (Kessler, 2018, p. 211). They can engage in project-based learning experiences and participate in social communicative tasks using these tools to allow them to explore and use the technological applications in real life (Kessler, 2018). Teachers can be provided with the support while learning to use the technologies, reflect on their own technology learning experiences, give feedback on the technologies, gain competence and confidence in their technological skills, and, in turn, apply these digital projects in language teaching.

This study's findings suggest the need to review educational technology standards and frameworks within teacher education programs. The teachers who received training in presentation software in their preservice education utilized the same technology in the classroom (Parra et al., 2019). Those who 
experienced technology training differently explored digital literacies in language teaching purposely because their learning experiences gave them a different perspective on the use of classroom technology. Therefore, more Web 2.0 technologies associated with new literacies need to be included in teacher preparation programs. Because teachers "tend to teach the way they were taught" (Parra et al., 2019), student teachers will benefit from modelling, familiarization, utilization, and training in the emerging technological tools during their preservice education to identify the affordances of these new tools and spaces (Kessler, 2018; Nelson et al., 2019; Parra et al., 2019).

\section{Limitations and Areas of Future Research}

The study looked at three high school language teachers' beliefs about digital technologies and their affordances for personal and professional use and how these have affected their teaching practices. Although studies on a larger scale are necessary, a survey and case study methodology and a small sample size proved useful in conducting a deeper investigation into teachers' digital mindsets and teaching pedagogy. This study's findings contribute to a better understanding of the digital mindsets of language instructors, but generalizability to the larger population is limited.

Although the three instructors provided a glimpse of what teachers' mindsets toward digital technologies might be, future studies should be conducted within a longer time frame for more robust data collection and analysis. Results might be different if participants were interviewed several times during the data collection period for a more in-depth exploration of teachers' beliefs to determine if their views toward technologies change over time with more engagement and training in using technology for language learning. The data collection site could also be expanded to other schools within the local community and more second/additional language instructors could be interviewed as the examination of a larger sample of participants may lead to a more insightful inquiry on the sociocultural influence on teachers' digital mindsets.

\section{Acknowledgement}

I wish to thank the administration and teachers for granting me permission to collect data for this study. I owe a special thanks to my supervisor at York University for his continued guidance and support. I am also grateful to the editors and anonymous reviewers for their insightful comments and suggestions on earlier versions of this article.

\section{The Author}

Sofia Cementina is a course coordinator and English for Academic Purposes (EAP) specialist in the McMaster English Language Development (MELD) Program, Department of Linguistics and Languages, Faculty of Humanities at McMaster University. Her research interests include second language curriculum development and instruction, multimodal literacies, and sociolinguistics. 


\section{References}

Angay-Crowder, T., Choi, J., \& Yi, Y. (2013). Putting multiliteracies into practice: Digital storytelling for multilingual adolescents in a summer program. TESL Canada Journal, 30(2), 36-45.

Antoniadou, V. (2011). Using Activity Theory to understand the contradictions in an online transatlantic collaboration between student-teachers of English as a Foreign Language. ReCALL, 23(3): 233-251. https://doi.org/10.1017/S0958344011000164

Burnett, C. (2009). “That's more like how they know me as a person”: One primary pre-service teacher's stories of her personal and "professional" digital practices. Literacy, 43(2), 75-82.

Burnett, C. (2011). Pre-service teachers' digital literacy practices: Exploring contingency in identity and digital literacy in and out of educational contexts. Language and Education, 25(5), 433-449.

Coiro, J., Knobel, M., Lankshear, C., \& Leu, D. J. (2008). Central issues in new literacies and new literacies research. In J. Coiro, M. Knobel, C. Lankshear, \& D. J. Leu (Eds.), Handbook of research on new literacies (pp. 1-21). New York: Taylor \& Francis Group.

Derwing, T. M., Munro, M. J., \& Thomson, R. I. (2007) . A longitudinal study of ESL learners' fluency and comprehensibility development. Applied Linguistics, 29(3), 359-380. https://doi. org/10.1093/applin/amm041

Deyoe, M. M., Newman, D. L., \& Asaro-Saddler, K. (2014). Moving from professional development to real-time use: How are we changing students? In J. Keengwe, G. Onchwari, \& D. Hucks (Eds.), Literacy enrichment \& technology integration in pre-service teacher education (pp. 160-182). Hershey, PA: IGI Global.

Ertmer, P. A. (1999). Addressing first- and second-order barriers to change: Strategies for technology integration. Educational Technology Research \& Development, 47(4), 47-61.

Ertmer, P. A. (2005). Teacher pedagogical beliefs: The final frontier in our quest for technological integration? Educational Technology Research \& Development, 53(4), 25-39.

Gee, J. P. (2012). Social linguistics and literacies: Ideology in discourses. Abingdon, UK: Routledge.

Gonzalez, D., \& St. Louis, R. (2013). CALL in low-tech contexts. In M. Thomas, H. Reinders, \& M. Warschauer (Eds.), Contemporary computer-assisted language learning (pp. 217-239). London, UK: Bloomsbury.

Graham, L. (2008). Teachers are digikids too: The digital histories and digital lives of young teachers in English primary schools. Literacy, 42(1), 10-18.

Graham, L. (2012). Unfolding lives in digital worlds: Digikid teachers revisited. Literacy, 46(3), 133-139.

Hafner, C. (2014). Embedding digital literacies in English language teaching: Students' digital video projects as multimodal ensembles. TESOL Quarterly, 48(4), 655-685.

Haines, K. J. (2015). Learning to identify and actualize affordances in a new tool. Language Learning \& Technology, 19(1), 165-180.

Haines, K. (2016). Expanding the knowledge base of teachers' use of communication tools for language learning. System, 62, 102-112.

Harris, J., Mishra, P., \& Koehler, M. (2009). Teachers' technological pedagogical content knowledge and learning activity types: Curriculum-based technology integration reframed. Journal of Research on Technology in Education, 41(4), 393-416.

Hew, K. F., \& Brush, T. (2007). Integrating technology into K-12 teaching and learning: Current knowledge gaps and recommendations for future research. Educational Technology Research $\mathcal{E}$ Development, 53(3), 223-252.

Hixon, E., \& Buckenmeyer, J. (2009). Revisiting technology integration in schools: Implications for professional development. Computers in the Schools, 26, 130-146.

Johnson, D. M. (1994). Approaches to research in second language learning. In N. Elson (Dir.), GS/LAL 6500: Research methods in applied linguistics [Course kit]. Toronto, ON, Canada: York University Bookstore. (Reprinted from Approaches to research in second language learning, Copp Clark Professional, pp. 3-239). 
Johnson, K. E. (2009). Second language teacher education: A sociocultural perspective. New York: Routledge.

Kessler, G. (2018). Technology and the future of language teaching. Foreign Language Annals, 51, 205-218. https://doi.org/10.1111/flan.12318

Lankshear, C., Knobel, M., \& Curran, C. (2013). Conceptualizing and researching "new literacies." In C. A. Chapelle (Ed.), The encyclopedia of applied linguistics (pp. 1-8): Blackwell Publishing Ltd. https://doi.org/10.1002/9781405198431.wbeal0182

Lankshear, C., \& Knobel, M. (2006). New literacies: Everyday practices and classroom learning (2nd ed.). New York: Open University Press.

Lankshear, C., \& Knobel, M. (2011). New literacies: Everyday practices and classroom learning (3rd ed.). Maidenhead, UK: Open University Press.

Lantolf, J. P. (2007). Sociocultural source of thinking and its relevance for second language acquisition. Bilingualism: Language and Cognition, 10(1), 31-33. https://doi.org/10.1017/ S1366728906002768

Lantolf, J. P., \& Pavlenko, A. (2001). (S)econd (L)anguage (A)ctivity theory: Understanding second language learners as people. In M. P. Breen (Ed.), Learner contributions to language learning: New directions in research (pp. 141-158). Harlow, UK: Pearson Education.

Lawrence, G. (2001). Second language teacher belief systems towards computer-mediated language learning: Defining teacher belief systems. In K. Cameron (Presenter), C.A.L.L. - The challenge of change: Research \& practice (pp. 41-52). Exeter, UK: Elm Bank Publications.

Lawrence, G., Haque, E., King, J., \& Rajabi, S. (2014). Exploring the feasibility of e-learning in Ontario ESL programs. Contact, 40(1). Retrieved from http://www.teslontario.net/uploads/ publications/contact/ContactSpring2014.pdf

Lawrence, G. (2018). The role of language teacher beliefs in an increasingly digitalized communicative world. In B. Zou \& M. Thomas (Eds.), Handbook of research on integrating technology into contemporary language learning and teaching (pp. 140-160). Hershey, PA: IGI Global.

Lewis, C. (2007). New literacies. In C. Lankshear \& M. Knobel (Eds.), A new literacies sampler (pp. 229-237). New York: Peter Lang Publishing, Inc.

Lowe, V. (2011). Lev Vygotsky [Documentary]. Retrieved from https://www.youtube.com/ watch?v=d-Kpi4SzAVo

Merchant, G. (2009). Web 2.0, new literacies, and the idea of learning through participation. English Teaching: Practice and Critique, 8(3), 107-122.

National Council of Teachers of English (2013). The NCTE definition of 21st century literacies. Retrieved from http://www.literacyinlearningexchange.org/sites/default/files/2013_the_ ncte_definition_of_21st_century_literacies.pdf

National Council of Teachers of English (2013). NCTE framework for 21st century curriculum and assessment. Retrieved from http://www.ncte.org/library/NCTEFiles/Resources/Positions/ Framework_21stCent_Curr_Assessment.pdf

Nelson, M. J., Voithofer, R., \& Cheng, S. L. (2019). Mediating factors that influence the technology integration practices of teacher educators. Computers $\mathcal{E}$ Education, 128, 330-344. https://doi. org/10.1016/j.compedu.2018.09.023

Norton, B., \& Toohey, K. (2011). Identity, language learning and social change. Language Teaching, $44(4), 412-446$.

Park, S. H., \& Ertmer, P. A. (2007). Impact of problem-based learning (PBL) on teachers' beliefs regarding technology use. Journal of Research on Technology in Education, 40(2), 247-267.

Parra, J., Raynor, C., Osanloo, A., \& Guillaume, R. O. (2019). (Re)Imagining an undergraduate integrating technology with teaching course. TechTrends, 63, 68-78. https://doi.org/10.1007/ s11528-018-0362-x

PRB Teacher Technology Survey. (n.d.) Retrieved from https://www.surveymonkey.com/r/?sm= 8goALimqb5BR73iAU\%252BAzOA\%253D\%253D 
Prensky, M. (2001). Digital natives, digital immigrants. On the Horizon, 9(5). Retrieved from https://edorigami.wikispaces.com/file/view/PRENSKY++DIGITAL+NATIVES+AND+IMMI GRANTS+1.PDF

Razfar, A., Khisty, L. L., \& Chval, K. (2011). Re-mediating second language acquisition: A sociocultural perspective for language development. Mind, Culture, and Activity, 18(3), 195-215.

Reinders, H., \& Wattana, S. (2015). Affect and willingness to communicate in digital game-based learning. ReCALL, 27(1), 38-57.

Shin, D. (2014). Web 2.0 tools and academic literacy development in a US urban school: A case study of a second-grade English Language Learner. Language and Education 28(1), 68-85.

Swain, M., Kinnear. P., \& Steinman, L. (2015). Sociocultural theory in second language education: An introduction through narratives (2nd ed.). Bristol, UK: Multilingual Matters.

Toohey, K., \& Dagenais, D. (2015). Videomaking as sociomaterial assemblage. Language and Education, 29(4), 302-316.

Tour, E. (2015). Digital mindsets: Teachers' technology use in personal life and teaching. Language Learning and Technology, 19(3), 124-139.

Vygotsky, L. S. (1978). Mind in society: The development of higher psychological processes. Cambridge: Harvard University Press.

Ware, P. (2008). Language learners and multimedia literacy in and after school. Pedagogies: An International Journal, 3(1), 37-51.

Warschauer, M., \& Ware, P. (2008). Learning, change, and power: Competing frames of technology and literacy. In J. Coiro, M. Knobel, C. Lankshear, \& D. J. Leu (Eds.), Handbook of research on new literacies (pp. 215-240). New York: Taylor \& Francis Group. 